STATE OF ALASKA

DEPARTMENT OF NATURAL RESOURCES

Alaska Geologic Materials Center Data Report No. 415

\title{
No. 415
}

Raven, R. and Chemostrat Inc., 2012, ICP Optical Emission and Mass Spectrometry data of cuttings from the Kalubik \#3, Colville Delta \#2, and E. Harrison Bay St. \#1 wells

Spreadsheet available for download

Received October 2012

All data reports may be downloaded free of charge from the DGGS website. 